\title{
Color Words between English and Chinese
}

\author{
Xuezhi Li \\ School of Business \\ Linyi University \\ Linyi, China \\ e-mail: lixuezhisd@126.com
}

\begin{abstract}
Color words are expressive language with profound culture meanings. This thesis provides a large number of examples to illustrate the cultural connotations of the basic color terms: black, white, red, yellow and green. It can help the readers know their cultural connotations clearly in English and Chinese, and appreciate the psychological differences so as to reduce the difficulties in intercultural communication.
\end{abstract}

Keywords-Basic color terms; cultural connotations; contrastive study

\section{INTRODUCTION}

In order to have a full understanding of the meanings of a word, the best way is to put the study of the word under the whole culture background of a society.

\section{COLOR OF RED}

\section{A. Red Color in Chinese Culture}

\section{1) Good fortune, jubilation and popularity}

The color of red has the meaning of good luck or something that goes smoothly. At the opening of a business or the opening ceremony of a fair, red ribbons are cut because they are thought to bring good fortune and success. 开门红 "have a good start" symbolizes good fortune, 红运“good luck", are both good examples. In the wedding ceremony, birthday party and some special days, people will use something red to add happiness. So the color of red in Chinese is the symbol of happy, lucky and joy. The red also conveys popularity, such as 大红大紫,红人, 走红 which means a good business.

\section{2) Wealth and healthy}

In ancient China, red is a graceful color, symbolizing wealth and high social position. In archaic Chinese buildings, columns, doors, windows and other structural components of palaces, temples and noble houses are painted in red. In addition, nobles, high officials and rich people are dressed in red. What's more, color of red can express psychological states, such as 满面红光 “radiant with happiness”, 面色红润“in very good health", and so on.

\section{3) Female}

The Chinese color terms 红颜 and 红粉佳人 are used to imply a beautiful or young woman. 红妆 also means a woman in rich attire

4) Jealousy

If someone is getting "red" (become popular and successful), others would envy or feel jealous of him. Such as, 红眼病 does not mean any disease at all, instead,it means someone is jealous.

\section{5) Danger, deficit and warning}

Red is also the color of fire, blood and war, thus red means dangerous, such as the red light in traffic regulations serves as a sign reminding and warning drivers to stop.

\section{B. Red Color in Western Culture \\ 1) Celebration and happiness}

It is true in both English-speaking countries and China that the color of red is usually related to celebrations and joyful occasions. In the western world, red encourages people to take actions. In this sense, red represents life, birth, love, warmth, passionate and celebrative. The expression "to paint the town red" means to enjoy a lively, boisterous time in public places.

\section{2) Danger and obsceneness}

According to Bible, blood is a symbol of misery, so red became associated with dangers for English-speaking people. "Red alert" means contingency alarm, which is the highest among the 5 ranks of alert. Red also means cruel, obscene in English. Red Badge of Courage is a novel describing the cruelty of war. Scarlet, a kind of deep red, symbolizes shame in Nathanial Hawthorne's novel.

\section{3) Over elaboration}

"Red tape" means the rigid application and observation of rules and regulations in all their minute details without regard for the end they were designed to achieve.

\section{4) Anger and embarrassment}

"To see red" and "waving a red flag" both are associated with anger. "To become red-faced" or "her face turned red" also shows embarrassment. 


\section{WHITE COLOR}

\section{A. White Color in Chinese Culture}

\section{1) Peace and success}

A successful period is called "the white moment of life". Ancient Chinese people believe that the white-feathered animals, such as 白鹿, 白鹤, 白天鹅. White pigeons have the reputation of the symbol of peace.

\section{2) Impoverishment, illiteracy and innocence}

The color term Bai has been used to refer to illiterate or uneducated as in 白衣 and 白丁. In addition, the color of white can be used to mean poverty as in 白屋, 白衣举人. The Chinese expressions 清白无辜 and 洁白无暇 are explicitly related to innocence and purity.

\section{3) Emotional meanings}

White means the aged in Chinese. Thus in Chinese, 白发 “gray hair" means the elderly. 苍白 “pale”, means this person may be anxious, sad, frightened or irritated. And 白眼 is an indication of contempt.

\section{4) Reactionary}

In contrast to red, white means the reactionary. For example, the area governed by Kuomintang during the second Revolutionary Civil War was called 白区. The terror created by counter-revolutionary violence were called 白色恐怖 "White Terror".

\section{5) Death}

In ancient China, no matter how low an official ranked, his robe was colored. White had never been the color of official robes because of the customary practice of taking white as the color of mourning dress. Consequently, white becomes the symbol of death.

\section{B. White Color in Western Culture}

\section{1) Virtue, Honesty and Uprightness}

"Whitewash" is to wash until it is white, but in a negative way, it means a deliberate concealment of someone's mistakes or faults in order to clear their name. A "white witch" or "white wizard" has a "white spirit or soul", using his or her "white magic" to do good deeds for people, and therefore he or she is "white-handed".

\section{2) Happiness and brightness}

In Christianity, white is the most sanctified color. The priests wear white robes, symbolizing spirit and brightness. In western countries, wedding is called white wedding, in which the bride wears white wedding robe and white sheer, the cakes and cookies are covered with a layer of white sugar, and the invitation card is printed in white silver letters. A famous saying by Ralph Waldo Emerson: "The grey past, the white future".

\section{3) Uselessness and in vain}

White means uselessness in "white elephant". And the expression "white elephant" is still used in modern times, indicating the completely useless things, although they may cost a lot of money.

\section{4) Big size and coward}

"White goods" is a word used especially in business meaning large pieces of equipment used in the house, such as washing machines, refrigerators, and so on, White in English also means coward. A "white-livered" person will "show the white feather" in danger and difficulty.

\section{BLACK COLOR}

\section{A. Black Color in Chinese Culture}

\section{1) Nobility, uprightness and impartiality}

In ancient China, the color of black was greatly admired. 细 衣, made by black silk, was put on when the ministers were having an audience with the emperor. Now, black becomes the holiest color in Chinese color outlook. In the types of facial makeup in operas, black face usually represents the noble characters as uprightness, selflessness of some historic figures. Such as, 铁面无私 is used to describe an impartial person. Therefore, black usually symbolizes impartiality, unselfishness, and justice.

\section{2) Illegality}

Such as 黑社会 “underworld”, 黑店 “inn run by brigands", 黑幕 “shady deal”, etc. In ancient China, 抹黑 “paint in black", the expression extended from the punishment, is very much similar to the English expression "black mark", an indication of failure or discredit. Therefore, black has the meaning of shame. 背黑锅 means take the blame for others.

\section{3) Darkness}

The color of black is often associated with negative qualities. In Chinese, as the hell in Christianity, the nether world in the mythologies is a dark place without any light and is said to be homes for all the wicked people to return to after their death. Another form is simply 黑, which mainly conveys the idea of darkness, danger, rebellion. For example, 黑压压, 黑灯瞎火 all means darkness.

\section{B. Black Color in Western Culture}

\section{1) Profit}

In business English, "in the black" has a good meaning of running a business profitably.

\section{2) Dignity}

"Black suit" or "black dress" is traditional clothes mostly upheld by the westerners.

\section{3) Sorrow, misfortune and disaster}

Black in English is associated with melancholy, pessimism, sorrow and misfortune, for example, "black art" "Blackball" "Black Death" "Black-letter day" etc.

\section{4) Depression}


The meaning of color of black is depressed, such as "Black dog”(沮丧), “black thoughts”（悲观的思想）, “ black browed"(愁容满面) and so on.

\section{5) Bad and evil}

English phrases like "black market”(黑市), "blacklist”(黑 名单), “black hand"(黑手党) show that black is related to the feature of the bad and the evil. "A black sheep" refers to that member in a groups who is thought to be a disgrace to other members. "A black lie" means a lie, which is full of evil intentions. The ballet opera Swan Lake, the black swan is the symbol of viciousness, deception and hatred.

\section{GREEN COLOR}

\section{A. Green Color in Chinese Culture}

\section{1) Youth and vigor}

In Chinese, we use either 绿 or 青 to refer to the color of green, therefore 青春, comes from the meaning of "green spring" refers to youth and vigor.

\section{2) Safety and permission}

As is the case in many other countries, green means safety, hope and peace in China. When the "green light" is on, safe passage is assured. Therefore, 开绿灯, which actually means "to give permission" or "provide convenience" in Chinese.绿 色通道 is a passage without obstacles, which is convenient and efficient for passengers, for example.

\section{3) Environmental protection and health}

With the worsening of pollution, people realize the importance of environmental protection, thus the color of green are connected closely with the environment. For instance, 绿色革命 "green revolution" originally refers to an increase in the amount that is produced by crops, such as improved scientific methods of farming. And others like 绿色食品 “organic foods”, 绿色和平组织 “Green-Peace”, 绿色消费 "green consumption".

\section{4) Humbly born and degradation}

In Chinese, green can be used to mean humble, degrading or bad reputation, the origin of which may be dated back to ancient China when green of color was regarded as impure. In modern China, some expressions can still be found, such as 绿 帽子 “green scarf” and 青楼女子 “brothel”. The former is not necessarily a green hat but often indicates a cuckold while the latter refers to a woman driven to be a prostitute.

\section{B. Green Color in Western Culture}

\section{1) Vigor, youth and permission}

Both in English and Chinese, green are associated with vigor and permission. For example, to remain green forever means to keep fresh and vigorous forever. Green light in English is associated with authoritative permission to go ahead with traffic regulations.

\section{2) Green plants}

Green is often associated with fruits and vegetables or gardening. In British English a green grocery is the business of a greengrocer. Further examples may include greenhouse and green fingers, which means the gift of being successful at gardening.

\section{3) Money or fortune}

The color of green in English is one of the favorite colors, and many places are decorated with green color and even US dollars carry the color of green. Therefore, the term green usually refers to money or fortune, as in American political elections the candidates that win are usually the ones who have green power backing them. "Green back" refers to American dollars; "green power" is power of money or financial group. "Green pound" refers to pounds of high rate of exchange in calculating the prices of agricultural products in EEC.

\section{4) Jealousy and envy}

In English green is often associated with jealousy and envy. "Green-eyed", "green with envy", and "green-eyed monsters" all mean jealousy and envy. However, in Chinese, we use 眼红 to describe envy or jealousy.

\section{5) Inexperience}

As in "you're expecting too much of him. He is still green to his job", green is used to indicate the lack of experience, training or knowledge. "A greenhorn" refers to a raw, simple and inexperienced person easily fooled or parted from his money.

\section{YeLLOW COLOR}

\section{A. Yellow Color in Chinese Culture}

\section{1) Good luck and precious time}

People use the idiom“飞黄腾达” to imply a rapid advance and good luck in one's official career. In Taoism and Buddhism, yellow is also a holy color. Some monks and Taoist priests wear yellow dresses. 黄道吉日 “a propitious date” is a day suitable for doing some important things, such as weddings and opening ceremonies. People call the most precious time as 黄金季节 and the youth of one's life 黄金时 代 “golden age", as it is the most valuable period in one's life.

\section{2) Imperial power}

In Chinese traditional culture, color of yellow has been used to symbolize imperial power. it is the specific color which only can be used by the emperors. There are many phrases with yellow to indicate the emperor. The carriage the emperor took is called 黄屋; an imperial edict is called 黄榜; clothes worn by the emperor are huangpao (黄袍) and so on.

\section{3) Holiness and dignity}

Color of yellow is the topmost color which is seen as the Chinese original color. Born with yellow skin, cultivated in the yellow soil, and taking the Yellow River as their place of origin, the Chinese people take pride in their identities. Call themlves proudly as 炎黄子孙.

4) Ripeness and immaturity 
One point that deserves mentioning is that the color of yellow in China conveys the meaning of ripeness and immaturity. 金黄的麦穗 obviously refers the fields turn golden yellow when the wheat is ripe for harvest, while 黄口小 儿, on the contrary, refers to babies, mostly referring to ignorant youngsters..

\section{5) Sickness and physical weakness}

In 面黄肌瘦 “sallow and emaciated”, the color of yellow is describing one's face, showing he looks pale and thin, not healthy.

\section{6) Failure and obsoleteness}

Yellow in Chinese is sometimes also associated with things out of date. For example, 明日黄花 and 黄粱美梦 are used figuratively to mean things in the past and unrealistic imagination respectively. In colloquial Chinese, yellow can also be used to indicate failure, such as 买卖黄了 “the deal is off'.

\section{B. Yellow Color in Western Culture}

\section{1) Holiness}

As the color of gold and sun, yellow is the symbol of power, honor and wealth. It's a holy color in Christianity. The holy cup used by Jesus in his last supper is also yellow.

\section{2) Welcome and support}

In English, there is a phrase "a yellow ribbon", according to Wikipedia, is a symbol with various meanings, mostly associated with those waiting for the return of a loved one or of military troops who are temporarily unable to come home. Recently, it has been used to symbolize support for the International Suicide Prevention Program and to raise awareness of Testicular Cancer, Endometriosis, and Madeleine McCann.

\section{3) Warning}

"A yellow-colored" card used in sports, shown to a player, as a caution that he has committed a flagrant foul. "Yellow alert”(黄色预警)—a condition of readiness to deal with a situation of great danger.

\section{4) Cowardice, betrayal and jaundice}

In the English language, yellow has traditionally been associated with jaundice and cowardice. In American slang, a coward is said to be a "yellow bellied" person. Yellow is also used to mean "jealousy", because Judas, who betrayed Jesus, wore yellow dress. Thus "yellow with envy" is usually used alternatively with "green with envy".

\section{5) A telephone book}

In Britain and America, the Yellow Pages don't mean obscene books, but a list of companies and organizations with their telephone numbers. It is called Yellow Pages just because the pages of the book are printed in yellow color.

\section{6) Vulgar}

The phrase "yellow journalism" refers to a kind of journalism with heavy emphasis on scandals, or presenting ordinary news in a sensational manner, sometimes even distorting the facts to create a sensational effect.

\section{CONCLUSION}

Different environments often cause different usage and understanding of the color terms, endowing them with cultural features of a nation.

Language is a social phenomenon, developing with the development of society. The evolution of political and economic system, division and reunion of society, contacts among societies, all these have been promoting the development of languages.

Religion writings enables a culture to pass on the wisdom of that culture from generation to generation. The usage of color in religions and their sacred writings exert great influence on the connotations of the color terms.

Besides the factors mentioned above, there are other factors influencing the usage of color terms. Some expressions with color terms come from myths. What's more, the usages of some expressions come from historical stories no matter it is true or not.

\section{REFERENCES}

[1] JIANG Dong-yuan, On the Cultural Differences of Color and Color Words.[J]Journal of Sichuan International Studies University,Mar1, 2002.

[2] PANYan - Ping,How to Use And Translate the Words of Cloror in English and Chinese.[J]Journal of Guangzhou University ,Vol.15 No.10.

[3] YUANG Bei-bei,The Analysis and Coordination Translation of the Extended Meaning between E-C Basic Color Words.[J]Overseas English 2012.02.

[4] LIN Yin,An Analysis of the Similarities and Differences of Chinese and English Color Words Meaning from a Cognitive Perspective.[J]Journal of Shaoguan University .Feb.2009. 